\title{
Update from the 4th Edition of the World Health Organization Classification of Head and Neck Tumours: Paragangliomas
}

\author{
Michelle D. Williams ${ }^{1} \cdot$ Arthur S. Tischler $^{2}$
}

Received: 25 November 2016 / Accepted: 2 February 2017 / Published online: 28 February 2017

(C) Springer Science+Business Media New York 2017

\begin{abstract}
Updated editions of The World Health Organization Classification of Tumours Pathology \& Genetics for both Head and Neck Tumours and Tumours of Endocrine Organs took place in 2016 based on consensus conferences. These editions present unification of concepts in paragangliomas and highlight expanding knowledge of their etiology. There is a major emphasis in the new bluebooks on familial/syndromic paragangliomas, representing $~ 40 \%$ of all head and neck paragangliomas. Ancillary use of immunohistochemical evaluation, specifically of SDHB, allows the pathologist to screen for a large subset of these potentially hereditary cases. In addition, similarly to other neuroendocrine tumors, paragangliomas are now considered to represent a continuum of risk, and are assessed in terms of risk stratification. Tumors with $S D H B$ mutations pose the highest risk for metastasis. There is currently no validated or endorsed histologic grading system. Paragangliomas remain tumors of undetermined biologic potential and should not be termed benign.
\end{abstract}

Keywords Paraganglioma - Carotid body tumor · SDHx · SDHD $\cdot$ Paraganglioma syndromes

Special Issue: World Health Organization Classification Update

Michelle D. Williams

mdwillia@mdanderson.org

Arthur S. Tischler

atischler@tuftsmedicalcenter.org

1 Department of Pathology, Head and Neck Section, University of Texas MD Anderson Cancer Center, 1515 Holcombe Blvd, Unit 085, Houston, TX 77030, USA

2 Department of Pathology and Laboratory Medicine, Tufts Medical Center, 800 Washington Street, Boston, MA 02111, USA

\section{Introduction}

In 2004, paragangliomas (PGL) were considered to be mostly sporadic tumors, with the exception of a few cases $(\sim 10 \%)$ associated with familial/genetic syndromes. During the past decade, germline mutations in more than 19 hereditary susceptibility genes resulting in PGL development have been identified [1]. More than 10 genes are associated with head and neck paragangliomas [2]. PGL now has the highest hereditary predisposition of any tumor ( $40 \%$ of cases), surpassing medullary thyroid carcinoma [3]. These findings have resulted in the identification of new familial syndromes and recognition of new syndromically associated tumors. Concurrently, the pathologist's role in patient management has expanded from pure histologic diagnosis and must adapt to the new genetic landscape. Evolving knowledge of PGL specific to the head and neck region has paralleled the broader investigation of PGLs occurring in other parts of the body.

\section{Genetics}

In 2004, at the time of the last World Health Organization (WHO) edition for Head and Neck Tumors, only a small subset of PGL were recognized to be genetically associated with three distinct chromosomal loci identified through familial genetic linkage and which the susceptibility genes were only partially delineated. Since that time, five syndromes with susceptibility genes have been defined and their associations with PGL in the head and neck region are being elucidated (Table 1) [1]. Other susceptibility genes for PGL and pheochromocytoma were also known including $V H L, R E T$ (MEN2), and $N F 1$, though these mutations have a relatively low association 
Table 1 Paraganglioma (PGL) syndromes and their associated genetic and clinical associations

\begin{tabular}{|c|c|c|c|c|c|c|c|}
\hline Syndrome & Gene & $\begin{array}{l}\% \text { of } \\
\text { patients with } \\
\text { HNPGLs }\end{array}$ & Risk for metastasis & $\begin{array}{l}\mathrm{PHEO} \pm \text { Thoraco/ } \\
\text { abdominal PGL }\end{array}$ & Associated tumors & FACT & Ref \\
\hline PGL1 & $\mathrm{SDHD}^{\mathrm{a}}$ & $79-89 \%$ & $4 \%$ & $12-53 \%$ & Renal, GIST, Pituitary & $\begin{array}{l}85 \% \text { occur in carotid } \\
\text { body PGLs }\end{array}$ & {$[1,51,52]$} \\
\hline PGL2 & $\mathrm{SDHAF}^{\mathrm{a}}$ & $73-86 \%$ & low & - & none to date & & {$[1,52]$} \\
\hline PGL3 & SDHC & $88 \%$ & $3 \%$ & Rare $<3 \%$ & Renal, (GIST) & $\begin{array}{l}\text { Usually present as soli- } \\
\text { tary PGLs }\end{array}$ & {$[1,51]$} \\
\hline PGL4 & SDHB & $27-62 \%$ & highest risk $23 \%$ & $18-84 \%$ & Renal, GIST, Pituitary & $\begin{array}{l}\text { Much more common } \\
\text { in intraabdominal \& } \\
\text { pelvic PGLs }\end{array}$ & {$[1,51,53]$} \\
\hline PGL5 & SDHA & $?$ & low & possible & (Renal), GIST, Pituitary & & {$[1,54]$} \\
\hline
\end{tabular}

Tumors in () are rare

GIST gastrointestinal stromal tumor, $H N$ head and neck, $P G L$ paragangliomas

${ }^{a}$ These genes are inherited with imprinting, thus parenteral inheritance is required for associated PGL development

with PGL development in the head and neck (HN) region [1] and are identified in both sporadic and hereditary PGLs [3, 4]. Through both germline and somatic tumor testing of individuals with PGL, the prevalence of germline susceptibility genes altered in HNPGL is now $\sim 30$ to $40 \%$, involving predominantly genes encoding subunits of succinate dehydrogenase ("SDHx" genes) [3,5]. In addition to $S D H x, V H L, N F 1$ and RET, genes including MAX [6], TMEM127 [7] fumarate hydratase [8] and HIF2A [9] have now been associated with HNPGL in rare cases. The clinical implications of hereditary disease have led the Endocrine Society to recommend referring all patients diagnosed with PGL for clinical genetic testing regardless of site of origin or lack of familial events [10].

PGL harboring $S D H \mathrm{x}$ and $V H L$ mutations comprise a cluster characterized by pseudohypoxic signaling pathways, with stabilization of the hypoxia-inducible transcription factors HIF1A and HIF2A (EPAS1) and increased expression of their downstream targets including VEGF, GLUT1, and glycolytic enzymes. These characteristics enable normal cells to survive and grow in low-oxygen environments [1]. A second susceptibility gene cluster with a greater predilection for pheochromocytomas and sympathoadrenal paragangliomas involves RET, RAS/MAPK/PI3K /mTOR pathways [3]. The two major clusters can be further divided according to phenotypes associated with individual genes [9, 11]. Although some sporadic PGL or pheochromocytomas harbor somatic rather than germline mutations of hereditary susceptibility genes, germline mutations of these genes are much more common. Somatic mutations of SDHx genes are extremely rare [3].

\section{Succinate Dehydrogenase (SDHx) Genes}

Interestingly, most of the susceptibility genes for HNPGL are related to the Krebs cycle [1]. Collectively the most prevalent are SDHx genes [12]. SDHD mutations represent $\sim 80 \%$ of mutations associated with HNPGLs, followed by SDHB at $\sim 20 \%$ and the remainder SDHC. The succinate dehydrogenase enzyme is made up of four separately encoded subunits designated SDHA, SDHB, SDHC, and SDHD plus flavination/assembly factor SDHAF2. Succinate dehydrogenase is a mitochondrial enzyme that serves as the link between the Krebs cycle and the electron transport chain, where electrons produced in the process of converting succinate to fumarate are used to produce ATP by oxidative phosphorylation. In the absence of functional $\mathrm{SDH}$, ATP is produced by the far less efficient process of glycolysis. This mechanism, known as aerobic glycolysis or the Warburg effect, is utilized variably in combinations with oxidative phosphorylation in many tumors, but is a hallmark of tumors lacking SDH or VHL. The tradeoff for decreased energy production is utilization of glycolytic pathway intermediates to generate carbon skeletons needed for synthesis of nucleotides, proteins and other macromolecules involved in cell proliferation and tumor growth [13]. SDHx mutations are almost exclusively hereditary to date making it an ideal screening target to identify patients and families that would benefit from further genetic evaluation and counseling.

While all of the mutations of hereditary susceptibility genes are considered autosomal dominant, SDHD and SDHAF2 mutations usually require transmission via the paternal carrier in order for disease to be manifested. Familial susceptibility to PGLs caused by these genes can 
be passed on by either parent, but the tumors will only develop if the mutation is inherited from the father. The mechanism is not fully understood but apparently differs from maternal imprinting of other genes [14]. This phenomenon poses challenges in identifying germline patients through family history alone as generations may be skipped when transmission is maternal.

An additional unusual relationship of SDH to PGL is Carney Triad, consisting of PGL, SDH-deficient GIST and pulmonary chondroma. The triad is not hereditary. While some cases are caused by epigenetic silencing of $S D H C$, the causative defect is unknown in most patients [15]. Despite the absence of hereditary transmission to date, occasional patients harbor germline sequence variants in $S D H A, S D H B$ or $S D H C$ [16].

\section{New Syndromic Associations}

In addition to PGLs, tumors now associated with germline SDHx mutations include GISTs, renal cell carcinomas and pituitary adenomas. The combination of GIST and paraganglioma, known as Carney-Stratakis dyad or Carney-Stratakis syndrome, is not a specific genetic disorder and can be seen in patients with mutations of SDHB, SDHC or SDHD, as well as in Carney triad. SDH-deficient GISTs typically arise in the stomach in young patients, have an epithelioid morphology, are often multifocal and frequently show plexiform involvement of the gastric wall [17]. SDH-deficient renal cell carcinomas arise in patients with a median age of 40 and often have a characteristic histologic appearance consisting of monomorphic polygonal eosinophilic cells with flocculent, bubbly and vacuolated cytoplasm, cysts and entrapped tubules $[18,19]$. In contrast, SDH-deficient pituitary adenomas may not show distinctive morphology [20]. Clinicians should be alert to the possibility of these syndromic tumors occurring in patients with paragangliomas. Conversely, because any of the tumors can arise earlier than paragangliomas, they can be the first clue to the presence of paraganglioma syndromes. Immunohistochemistry for SDHB can help to identify SDH-deficient tumors and should be considered when these types of tumors have unusual features or present in patients or families with unusual histories.

\section{Immunohistochemical Evaluation}

While the current medical recommendation is for all patients with PGL to have available clinical genetic counseling, local resources may be limited. Immunohistochemical evaluation of SDHB is a tool pathologists can use to screen paragangliomas for possible mutations in SDHx genes. SDHB expression is evaluated by looking for granular cytoplasmic staining in the paraganglioma cells. Loss of expression is an abnormal finding seen in the majority of PGLs with syndromically associated tumors from patients with SDHx germline mutations [21-23] and in Carney triad. Absent expression is only meaningful and can only be reported if there is staining of normal tissue (i.e. endothelial cells and inflammatory cells) identified within the tissue as an internal control (Fig. 1c). Loss of SDHB does not specifically signify which SDHx gene is altered. SDHB immunohistochemical evaluation is a surrogate marker for alterations/mutations in any of the SDHx family of genes. As SDHB is part of a protein complex with SDHA, SDHC and SDHD, mutation of any of these genes lead to conformational protein change of SDHB and secondary loss of detection by immunohistochemistry [21]. Thus careful wording of SDHB expression patterns in PGL and their potential significance is needed. Example reporting could include: "Immunohistochemical evaluation for SDHB expression is lost in the PGL cells with positive internal control identified. This immunohistochemical study is a general screening process and is not specific for mutations in the SDHB gene but is seen when any of the SDHx family of genes is altered (SDHA, B, C, or D). As the vast majority of SDHx mutations are familial in PGL, further genetic evaluation is advised".

A caveat is that caution is required when examining tumors for SDHB expression after embolization when inflammatory cells are numerous, as they will show positive SDHB staining. Thus, recognizing negative PGL cells admixed with the reactive inflammation is needed for correct interpretation (Fig. 1d). While there is now an antibody for SDHA for which loss of expression is specific for SDHA gene alterations; SDHA has only rarely been associated with HNPGLs [24]. Thus its added value in HNPGL is limited at this time.

\section{Clinical Significance of Different Germline Mutations}

Specific SDHx mutations have different implications, both for the behavior of individual tumors and systemically [25]. These innate risk factors allow for improved counseling and monitoring of patients and families. SDHD, the most frequently mutated gene in HNPGLs, is often associated with multifocal tumors located predominantly in the head and neck (up to $60 \%$ multifocality), with lower but significant probability of pheochromocytomas and thoracoabdominal sympathoadrenal paragangliomas. The opposite is true for SDHB, which is more often associated with thoracoabdominal tumors and somewhat less with multifocality. Although all mutated SDHx genes carry a risk for metastasis, SDHB 


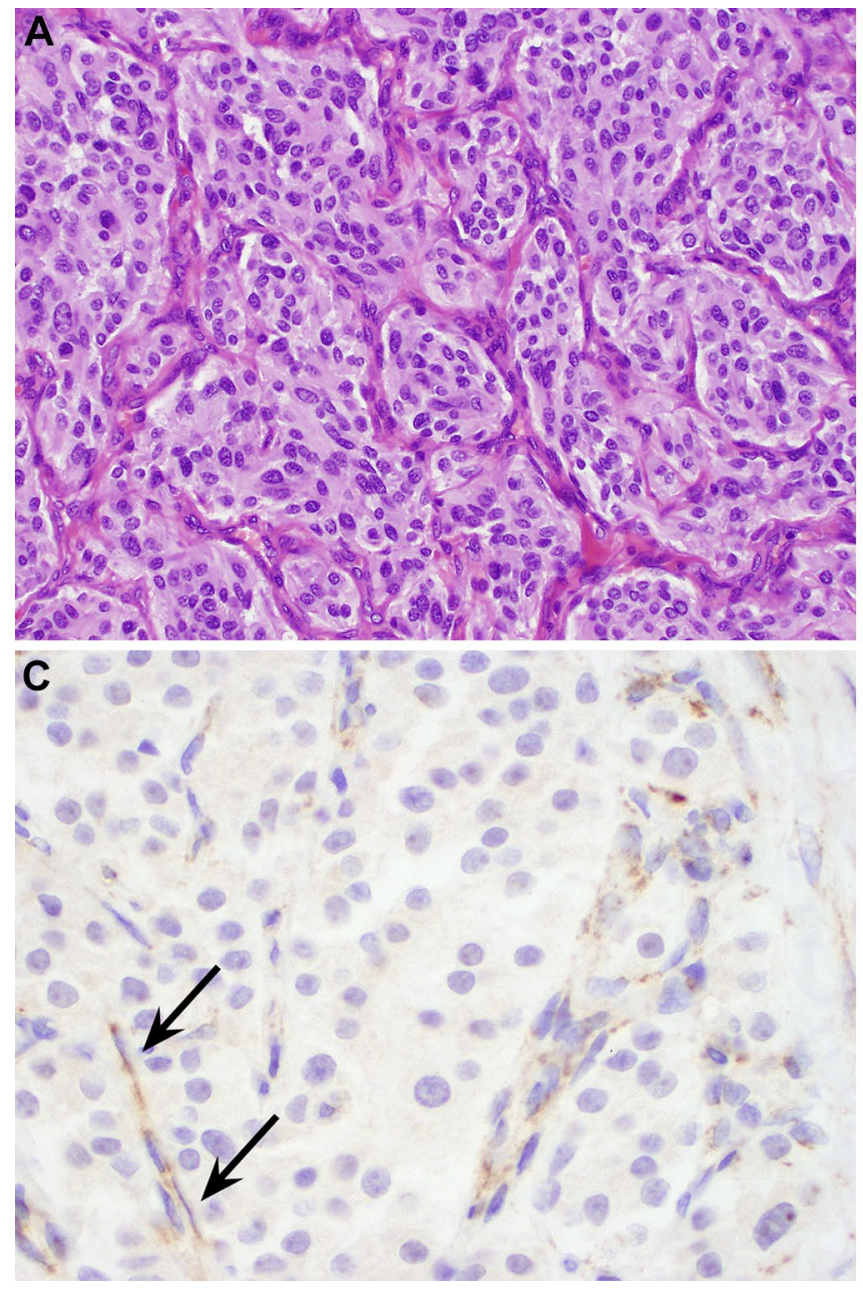

Fig. 1 Immunohistochemical evaluation for SDHB expression is a screening tool for possible genetic association. a H\&E evaluation highlights the mixed cellular population present in paragangliomas including the rich vascular network around the zellenballen tumor structure. b Normal SDHB expression is granular in the cytoplasm and is identified in both the PGL cells, as well as, in the background tissues (endothelial cells and inflammatory cells). c Loss of SDHB

mutations confer the highest risk at $\sim 30 \%$, while only $3-4 \%$ of PGL with SDHD and probably fewer with SDHC mutations metastasize. SDHB mutations are also associated with the poorest survival (11-36\% at 5 years) [26, 27]. For these reasons, while many patients with HNPGL can be managed by active surveillance, those with SDHB mutations might in some cases be better served by early surgical intervention [28].

Prior to widespread genetic testing, multifocality was recognized as a common feature present in $80 \%$ of hereditary PGL and aided in identifying patients for further clinical evaluation. That observation was consistent with the current status of SDHD as the predominant mutated gene in HNPGLs and its association with multifocal tumors. While multifocality was also previously associated with

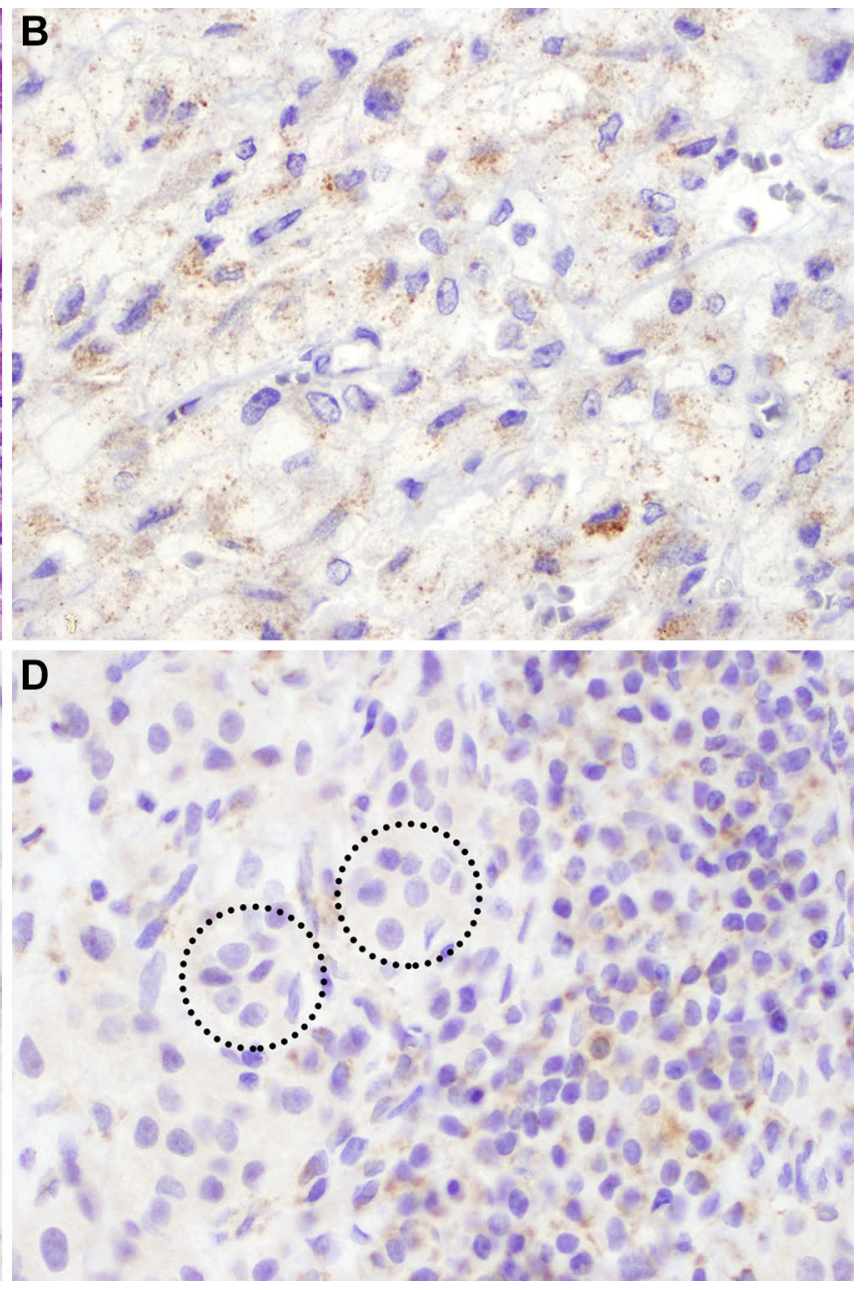

expression signifies a mutation in one of the SDHx family genes, however may only be reported when expression is present in the internal control cells (i.e. endothelial cells and inflammatory cells). d Careful evaluation of SDHB expression is needed as PGL cells with SDHB loss (circles) may be obscured when there is a high inflammatory component (right) where SDHB will be retained. Discuss each panel in the text in order

10-20\% of 'sporadic' HNPGL, it is estimated that 15-20\% of patients presenting as apparently sporadic HNPGL without family history will now test positive for a germline mutation. This absence of a notable family history may be accounted for by both the 'asymptomatic' growth of PGL in family members (as $<1 \%$ of HNPGLs are secretory) and the complex hereditary pattern of SDHD gene mutations, in which penetrance is usually tied to paternal transmission (described above). The significance of multifocality as a clue to hereditary disease is therefore stronger now than in previous years.

It is widely recognized that the ability to screen families for hereditary syndromes allows for earlier detection and surveillance both for paragangliomas and for associated tumors. However, the required scope and nature 
of surveillance will now vary in accordance with genotype- phenotype correlations as discussed above, together with institutional preferences and availability of resources. Thus, clinical genomic testing for (1) presence of an SDHx mutation and (2) which SDHx mutation is present, allows for approaching each patient with follow-up and screening focus on the related organ systems most likely involved [29, 30].

\section{HNPGL Sites of Involvement}

PGLs in the HN occur predominantly in four regions: the carotid body, the middle ear, vagus nerve and larynx. Information regarding PGL in each subsite remains delineated as separate chapters in the upcoming WHO.

The carotid body is the most common location encountered for HNPGLs representing $60 \%$ of cases. The tumor is located at the carotid bifurcation and may grow to encase the artery. Patients are generally asymptomatic as HNPGL are non-functional though may present with a palpable neck mass. There is a female predominance $(2: 1)$, which markedly increases when PGLs occur in high altitude societies [31,32]. The observation of bilateral and/or multifocal PGL is noted in up to $25 \%$ of carotid body PGLs and aligns with familial occurrence of predominantly SDHD mutations [33-37]. Aggressive behavior in the form of metastasis occurs in $\sim 4 \%$ of cases. Thus, in addition to the observation of bilateral carotid body paragangliomas, the recognition of risk for PGL including thoracic and/or abdominal based on the specific SDHx mutation increases the scope of screening when germline alterations are identified.

Middle ear PGLs represent approximately $30 \%$ of PGL diagnosed in the $\mathrm{HN}$ with a similar if not slightly narrower age of presentation (20-70's). The presenting symptom is often pulsatile tinnitis. Within the middle ear, PGLs may be associated with either the jugular bulb or tympanic nerve (Nerve of Jacobson) leading to petrous bone or middle ear involvement, respectively. Hereditary associations are common resulting in earlier presentation, multiple and/or bilateral PGL including concurrent carotid body PGL [38]. Immunohistochemical evaluation of SDHB may be used to screen for possible hereditary association as in PGLs of other sites. Distant metastasis may occur in up to 5\% of cases and appears more common in hereditary cases [39].

Vagal PGLs make up 10-15\% of PGL occurring in the $\mathrm{HN}$ region with a mean age of diagnosis in the 5 th decade. Clinical presentation at this site includes possible palpable neck mass, or uncommonly neuropathies, however most patients are asymptomatic with detection on imaging studies. Multicentric presentation occurs in $\sim 1 / 3$ rd of cases with the vast majority $(80 \%)$ of these having a documented family history of PGLs [40]. Anatomically the vagal nerve runs near the carotid bifurcation, thus careful evaluation of the relationship of the mass to the carotid bifurcation/ carotid body region by imaging allows for this distinction. Genetically, mutations in the SDHx family of genes accounted for all of the hereditary cases in one series (89\% with SDHD, 8\% with SDHB, and 1\% with SDHC) [41] though rare SDHAF2 have also been documented [42]. The metastatic rate may be higher for vagal PGL than other sites, $16 \%$ versus $2-6 \%$ for carotid body and middle ear PGL, with lymph nodes involvement accounting for the majority of cases [43, 44]. Further studies to clarify this rate are still needed, as multifocal PGL (second primary PGLs) versus true metastasis was not always excluded.

Laryngeal PGLs are rare and must be histologically delineated from neuroendocrine carcinomas, which are clinically aggressive [45]. Similarly, evidence of catecholamine production should raise the concern of neuroendocrine carcinoma and not paraganglioma, which are nonfunctional. Paraganglia are present in both the supraglottic and infraglottic larynx [46]. Presenting symptoms vary from stridor, to hoarseness and dyspnea. Their rarity limits available correlative data for mutation frequency, however overall metastatic rate is rare, estimated at 2\% [47-49].

\section{Histologic Review/Diagnosis}

Morphologic review remains the mainstay for the diagnosis of PGLs. Observation of nested (zellenballen) growth pattern with prominent surrounding vasculature is the classic pattern of growth seen in these tumors (Fig. 1a). Cytologically, PGL cells may show variability in size and often show partially clear cytoplasm. There is ample cytoplasm surrounding nuclei showing characteristic neuroendocrine features including hyperchromatic and hypochromatic areas (salt and pepper nuclei). Other growth patterns and histologic features including sclerosing, clear, and pigmented features have also been described and should be familiar to pathologists to consider this entity. Immunohistochemical evaluation for neuroendocrine markers (synaptophysin, chromogranin, etc.) with the absence of cytokeratins aids in confirming the lineage and classification as PGL.

PGL is classified by the WHO as a tumor of indeterminate biology M code XXXX1. Primary PGLs are not classified as benign or malignant and are considered to represent a spectrum of metastatic potential. A parallel change in both the Head \& Neck and Endocrine bluebooks is that once there has been spread to a regional lymph node or distant site the term "metastatic" PGL is utilized. The term malignant is thereby avoided entirely in order to avoid confusion concerning the definition of malignancy. A continued challenge remains that the histologic features 
Table 2 Updates in head and neck paragangliomas (HNPGL)

Genetics

$30-40 \%$ of HNPGLs are familial

Gene mutations involving the succinate dehydrogenate (SDH) pathway predominate, most commonly SDHD

Genetic associations in PGL maybe syndromic, highlighting the need to screen at risk carriers for both PGLs and other potential tumors (Table 1)

Inheritance is autosomal dominance with paternal inheritance required for SDHD associated PGLs

Histology/biology

PGLs are now considered to represent a continuum of risk, and are assessed in terms of risk stratification based on genetic associations and therefore should not be termed "benign"

There is no validated histopathologic risk assessment score for head and neck PGLs

Thus histopathologic features (i.e. soft tissue involvement, vascular invasion, mitoses, necrosis) are insufficient to determine risk for distant metastases

Loss of SDHB expression by immunohistochemistry is a valuable screening tool to identify any succinate dehydrogenase gene mutation (SDHA, B, C or D) in tumors

in HNPGL including local infiltration of surrounding soft tissue, necrosis and atypia do not reliably predict their biologic behavior. No scoring or grading system has been validated or endorsed for use with HNPGLs at this time.

\section{In Summary (Table 2)}

The pathologist's role in managing patients with HNPGL requires increased awareness of the hereditary basis of these tumors and syndromically associated neoplasms including GIST, renal cell carcinoma and pituitary adenoma. Germline mutations of genes encoding subunits of succinate dehydrogenase account for the majority of PGL in the head and neck. Their recognition promotes screening for associated tumors in affected patients and, conversely, recognition of associated tumors can lead to screening for paragangliomas [50]. Loss of immunohistochemical staining for SDHB protein is a valuable screening tool that can help to identify any succinate dehydrogenase gene mutation in most tumors. Histologic markers to predict metastasis and prognosis remain elusive in HNPGLs. In contrast, risk is currently best delineated by genetics, with the highest risk of aggressive behavior linked to $S D H B$ mutations. Thus in the last decade, our understanding of susceptibility genes in PGL has further defined individual and family risk for disease. Characterization of mechanisms by which the recently discovered susceptibility genes affect tumor metabolism and signaling pathways has begun to suggest approaches for targeted intervention and may open new roles for pathologists in future years.

\section{Compliance with Ethical Standards}

Conflict of interest The authors have no conflicts of interest to declare.
Ethical Approval This article does not contain any studies with human participants or animals performed by any of the authors.

\section{References}

1. Pacak K, Wimalawansa SJ. Pheochromocytoma and paraganglioma. Endocr Pract. 2015;21:406-12.

2. Boedeker CC, Hensen EF, Neumann HP, Maier W, van Nederveen FH, Suarez C, Kunst HP, Rodrigo JP, Takes RP, Pellitteri PK, Rinaldo A, Ferlito A. Genetics of hereditary head and neck paragangliomas. Head Neck. 2014;36:907-16.

3. Dahia PL. Pheochromocytoma and paraganglioma pathogenesis: learning from genetic heterogeneity. Nat Rev Cancer. 2014;14:108-19.

4. Castro-Vega LJ, Letouze E, Burnichon N, Buffet A, Disderot PH, Khalifa E, Loriot C, Elarouci N, Morin A, Menara M, LepoutreLussey C, Badoual C, Sibony M, Dousset B, Libe R, Zinzindohoue F, Plouin PF, Bertherat J, Amar L, de Reynies A, Favier J, Gimenez-Roqueplo AP. Multi-omics analysis defines core genomic alterations in pheochromocytomas and paragangliomas. Nat Commun. 2015;6:6044.

5. Fishbein L. Pheochromocytoma and paraganglioma: genetics, diagnosis, and treatment. Hematol Oncol Clin North Am. 2016;30:135-50.

6. Burnichon N, Cascon A, Schiavi F, Morales NP, CominoMendez I, Abermil N, Inglada-Perez L, de Cubas AA, Amar L, Barontini M, de Quiros SB, Bertherat J, Bignon YJ, Blok MJ, Bobisse S, Borrego S, Castellano M, Chanson P, Chiara MD, Corssmit EP, Giacche M, de Krijger RR, Ercolino T, Girerd X, Gomez-Garcia EB, Gomez-Grana A, Guilhem I, Hes FJ, Honrado E, Korpershoek E, Lenders JW, Leton R, Mensenkamp AR, Merlo A, Mori L, Murat A, Pierre P, Plouin PF, Prodanov T, Quesada-Charneco M, Qin N, Rapizzi E, Raymond V, Reisch N, Roncador G, Ruiz-Ferrer M, Schillo F, Stegmann AP, Suarez C, Taschin E, Timmers HJ, Tops CM, Urioste M, Beuschlein F, Pacak K, Mannelli M, Dahia PL, Opocher G, Eisenhofer G, Gimenez-Roqueplo AP, Robledo M. MAX mutations cause hereditary and sporadic pheochromocytoma and paraganglioma. Clin Cancer Res. 2012;18:2828-37.

7. Neumann HP, Sullivan M, Winter A, et al. Germline mutations of the TMEM127 gene in patients with paraganglioma of head 
and neck and extraadrenal abdominal sites. J Clin Endocrinol Metab. 2011;96:E1279-E1282.

8. Clark GR, Sciacovelli M, Gaude E, Walsh DM, Kirby G, Simpson MA, Trembath RC, Berg JN, Woodward ER, Kinning E, Morrison PJ, Frezza C, Maher ER. Germline FH mutations presenting with pheochromocytoma. J Clin Endocrinol Metab. 2014 Oct;99(10):E2046-E50.

9. Fliedner S Hypoxia-inducible factor $2 \alpha$ mutation-related paragangliomas classify as discrete pseudohypoxic subcluster. Neoplasia. 2016;18:567-576.

10. Lenders JW, Duh QY, Eisenhofer G, Gimenez-Roqueplo AP, Grebe SK, Murad MH, et al. Endocrine Society. Pheochromocytoma and paraganglioma: an endocrine society clinical practice guideline. J Clin Endocrinol Metab. 2014;99:1915-42.

11. Shankavaram U, Fliedner SM, Elkahloun AG, et al. Genotype and tumor locus determine expression profile of pseudohypoxic pheochromocytomas and paragangliomas. Neoplasia. 2013;15:435-47.

12. Baysal BE, Willett-Brozick JE, Lawrence EC, Drovdlic CM, Savul SA, McLeod DR, Yee HA, Brackmann DE, Slattery WH 3rd, Myers EN, Ferrell RE, Rubinstein WS. Prevalence of SDHB, SDHC, and SDHD germline mutations in clinic patients with head and neck paragangliomas. J Med Genet. 2002 Mar;39(3):178-83.

13. Mayers JR, Vander Heiden MG. Famine versus feast: understanding the metabolism of tumors in vivo. Trends Biochem Sci. 2015;40:130-40.

14. Baysal BE, Maher ER: 15 years of paraganglioma: genetics and mechanism of pheochromocytoma-paraganglioma syndromes characterized by germline SDHB and SDHD mutations. Endocr Relat Cancer. 2015;22:T71-82.

15. Haller F, Moskalev EA, Faucz FR, Barthelmess S, Wiemann S, Bieg M, Assie G, Bertherat J, Schaefer IM, Otto C, Rattenberry E, Maher ER, Strobel P, Werner M, Carney JA, Hartmann A, Stratakis CA, Agaimy A. Aberrant DNA hypermethylation of SDHC. a novel mechanism of tumor development in carney triad. Endocr Relat Cancer. 2014;21:567-77.

16. Boikos SA, Xekouki P, Fumagalli E, et al. Carney triad can be (rarely) associated with germline succinate dehydrogenase defects. Eur J Hum Genet 2016;24:569-73.

17. Miettinen M, Wang ZF, Sarlomo-Rikala M, Osuch C, Rutkowski P, Lasota J. Succinate dehydrogenase-deficient GISTs: a clinicopathologic, immunohistochemical, and molecular genetic study of 66 gastric GISTs with predilection to young age. Am J Surg Pathol. 2011;35:1712-21

18. Williamson SR, Eble JN, Amin MB, et al. Succinate dehydrogenase-deficient renal cell carcinoma: detailed characterization of 11 tumors defining a unique subtype of renal cell carcinoma. Mod Pathol 2015;28:80-94.

19. Gill AJ, Pachter NS, Chou A, et al. Renal tumors associated with germline SDHB mutation show distinctive morphology. Am J Surg Pathol. 2011;35:1578-85.

20. Dwight T, Mann K, Benn DE, et al. Familial SDHA mutation associated with pituitary adenoma and pheochromocytoma/paraganglioma. J Clin Endocrinol Metab. 2013;98:E1103-E1108.

21. van Nederveen FH, Gaal J, Favier J, Korpershoek E, Oldenburg RA, de Bruyn EM, Sleddens HF, Derkx P, Rivière J, Dannenberg H, Petri BJ, Komminoth P, Pacak K, Hop WC, Pollard PJ, Mannelli M, Bayley JP, Perren A, Niemann S, Verhofstad AA, de Bruïne AP, Maher ER, Tissier F, Méatchi T, Badoual C, Bertherat J, Amar L, Alataki D, Van Marck E, Ferrau F, François J, de Herder WW, Peeters MP, van Linge A, Lenders JW, Gimenez-Roqueplo AP, de Krijger RR, Dinjens WN. An immunohistochemical procedure to detect patients with paraganglioma and phaeochromocytoma with germline SDHB, SDHC, or SDHD gene mutations: a retrospective and prospective analysis. Lancet Oncol. 2009;10(8):764-71.

22. Gill AJ, Benn DE, Chou A, Clarkson A, Muljono A, MeyerRochow GY, Richardson AL, Sidhu SB, Robinson BG, CliftonBligh RJ. Immunohistochemistry for SDHB triages genetic testing of SDHB, SDHC, and SDHD in paraganglioma-pheochromocytoma syndromes. Hum Pathol. 2010;41(6):805-14. doi:10.1016/j.humpath.2009.12.005.

23. Papathomas TG, Oudijk L, Persu A, Gill AJ, van Nederveen F, Tischler AS, Tissier F, Volante M, Matias-Guiu X, Smid M, Favier J, Rapizzi E, Libe R, Currás-Freixes M, Aydin S, Huynh T, Lichtenauer U, van Berkel A, Canu L, Domingues R, CliftonBligh RJ, Bialas M, Vikkula M, Baretton G, Papotti M, Nesi G, Badoual C, Pacak K, Eisenhofer G, Timmers HJ, Beuschlein F, Bertherat J, Mannelli M, Robledo M, Gimenez-Roqueplo AP, Dinjens WN, Korpershoek E, de Krijger RR. SDHB/SDHA immunohistochemistry in pheochromocytomas and paragangliomas: a multicenter interobserver variation analysis using virtual microscopy: a Multinational Study of the European Network for the Study of Adrenal Tumors (ENS@T). Mod Pathol. 2015;28(6):807-21.

24. Korpershoek E, Favier J, Gaal J, Burnichon N, van Gessel B, Oudijk L, Badoual C, Gadessaud N, Venisse A, Bayley JP, van Dooren MF, de Herder WW, Tissier F, Plouin PF, van Nederveen FH, Dinjens WN, Gimenez-Roqueplo AP, de Krijger RR. SDHA immunohistochemistry detects germline SDHA gene mutations in apparently sporadic paragangliomas and pheochromocytomas. J Clin Endocrinol Metab. 2011;96(9):E1472-6.

25. Benn DE, Robinson BG, Clifton-Bligh RJ. 15 Years of paraganglioma: clinical manifestations of paraganglioma syndromes types 1-5. Endocr Relat Cancer. 2015;22:T91-103.

26. Lee JH, Barich F, Karnell LH, Robinson RA, Zhen WK, Gantz BJ, Hoffman HT; American College of Surgeons Commission on Cancer; American Cancer Society. National cancer data base report on malignant paragangliomas of the head and neck. Cancer. 2002;94(3):730-7.

27. Sethi RV, Sethi RK, Herr MW, Deschler DG. Malignant head and neck paragangliomas: treatment efficacy and prognostic indicators. Am J Otolaryngol. 2013;34(5):431-8. doi:10.1016/j. amjoto.2013.03.010.

28. Ellis RJ, Patel D, Prodanov T, Nilubol N, Pacak K, Kebebew E. The presence of SDHB mutations should modify surgical indications for carotid body paragangliomas. Ann Surg. 2014;260(1):158-62.

29. Dénes J, Swords F, Rattenberry E, Stals K, Owens M, Cranston T, Xekouki P, Moran L, Kumar A, Wassif C, Fersht N, Baldeweg SE, Morris D, Lightman S, Agha A, Rees A, Grieve J, Powell M, Boguszewski CL, Dutta P, Thakker RV, Srirangalingam U, Thompson CJ, Druce M, Higham C, Davis J, Eeles R, Stevenson M, O'Sullivan B, Taniere P, Skordilis K, Gabrovska P, Barlier A, Webb SM, Aulinas A, Drake WM, Bevan JS, Preda C, Dalantaeva N, Ribeiro-Oliveira A Jr, Garcia IT, Yordanova G, Iotova V, Evanson J, Grossman AB, Trouillas J, Ellard S, Stratakis CA, Maher ER, Roncaroli F, Korbonits M. Heterogeneous genetic background of the association of pheochromocytoma/paraganglioma and pituitary adenoma: results from a large patient cohort. J Clin Endocrinol Metab. 2015 ;100(3):E531-E41. doi:10.1210/ jc.2014-3399.

30. Jamilloux Y, Favier J, Pertuit M, Delage-Corre M, Lopez S, Teissier MP, Mathonnet M, Galinat S, Barlier A, Archambeaud F. A MEN1 syndrome with a paraganglioma. Eur J Hum Genet. 2014;22(2):283-5.

31. Lee JH, Barich F, Karnell LH, Robinson RA, Zhen WK, Gantz BJ, Hoffman HT. National cancer data base report on malignant paragangliomas of the head and neck. Cancer. 2002;94:730-7. 
32. Rodríguez-Cuevas S, López-Garza J, Labastida-Almendaro S. Carotid body tumors in inhabitants of altitudes higher than 2000 meters above sea level. Head Neck. 1998;20:374-8.

33. Amato B, Bianco T, Compagna R, Siano M, Esposito G, Buffone $\mathrm{G}$, et al. Surgical resection of carotid body paragangliomas: 10 years of experience. Am J Surg. 2014;207:293-8.

34. Langerman A, Athavale SM, Rangarajan SV, Sinard RJ, Netterville JL. Natural history of cervical paragangliomas: outcomes of observation of 43 patients. Arch Otolaryngol Head Neck Surg. 2012;138:341-5.

35. O'Neill S, O'Donnell M, Harkin D, Loughrey M, Lee B, Blair P. A 22-year Northern Irish experience of carotid body tumours. Ulster Med J. 2011;80:133-40.

36. Qin RF, Shi LF, Liu YP, Lei DL, Hu KJ, Feng XH, et al. Diagnosis and surgical treatment of carotid body tumors: 25 years' experience in China. Int J Oral Maxillofac Surg. 2009;38:713-8.

37. Sajid MS, Hamilton G, Baker DM, Joint Vascular Research Group. A multicenter review of carotid body tumour management. Eur J Vasc Endovasc Surg. 2007;34:127-30.

38. Carlson ML, Sweeney AD, Pelosi S, Wanna GB, Glasscock ME 3rd, Haynes DS. Glomus tympanicum: a review of 115 cases over 4 decades. Otolaryngol Head Neck Surg. 2015;152:136-42.

39. Manolidis S, Shohet JA, Jackson CG, Glasscock ME 3rd. Malignant glomus tumors. Laryngoscope. 1999;109:30-4.

40. Capatina C, Ntali G, Karavitaki N, Grossman AB. The management of head-andneck paragangliomas. Endocr Relat Cancer. 2013;20:R291-305.

41. Taïeb D, Kaliski A, Boedeker CC, Martucci V, Fojo T, Adler JR Jr, et al. Current approaches and recent developments in the management of head and neck paragangliomas. Endocr Rev. 2014;35:795-819.

42. Kunst HP, Rutten MH, de Mönnink JP, Hoefsloot LH, Timmers HJ, Marres HA, et al. SDHAF2 (PGL2-SDH5) and hereditary head and neck paraganglioma. Clin Cancer Res. 2011;17:247-54.

43. Capatina C, Ntali G, Karavitaki N, Grossman AB. The management of head-and-neck paragangliomas. Endocr Relat Cancer. 2013;20(5):R291-305. doi:10.1530/ERC-13-0223.

44. Heinrich MC, Harris AE, Bell WR. Metastatic intravagal paraganglioma. Case report and review of the literature. Am J Med. 1985;78(6 Pt 1):1017-24.
45. Ferlito A, Milroy CM, Wenig BM, Barnes L, Silver CE. Laryngeal paraganglioma versus atypical carcinoid tumor. Ann Otol Rhinol Laryngol. 1995;104(1):78-83.

46. Barnes L. Paraganglioma of the larynx. A critical review of the literature. ORL J Otorhinolaryngol Relat Spec. 1991;53:220-34.

47. de Azevedo-Gamas A, Gloor F. A very unusual case of tumor of the larynx. Unexpected anatomopathologic diagnosis. Ann Otolaryngol Chir Cervicofac. 1968;85:329-35.

48. Ferlito A, Barnes L, Wenig BM. Identification, classification, treatment, and prognosis of laryngeal paraganglioma. Review of the literature and eight new cases. Ann Otol Rhinol Laryngol. 1994;103:525-36.

49. Rüfenacht H, Mihatsch MJ, Jundt K, Gächter A, Tanner K, Heitz PU. Gastric epitheloid leiomyomas, pulmonary chondroma, non-functioning metastasizing extra-adrenal paraganglioma and myxoma: a variant of Carney's triad. Report of a patient. Klin Wochenschr. 1985;63:282-4.

50. Gimenez-Roqueplo AP, Caumont-Prim A, Houzard C, Hignette C, Hernigou A, Halimi P, et al., EVA Investigators. Imaging work-up for screening of paraganglioma and pheochromocytoma in SDHx mutation carriers:a multicenter prospective study from the PGL. J Clin Endocrinol Metab. 2013;98:E162-73.

51. Pasini B, Stratakis CA. SDH mutations in tumorigenesis and inherited endocrine tumours: lesson from the phaeochromocytoma-paraganglioma syndromes. J Intern Med. 2009;266:19-42.

52. Offergeld C, Brase C, Yaremchuk S, Mader I, Rischke HC, Glasker S, Schmid KW, Wiech T, Preuss SF, Suarez C, Kopec T, Patocs A, Wohllk N, Malekpour M, Boedeker CC, Neumann HP. Head and neck paragangliomas: clinical and molecular genetic classification. Clinics. 2012;67(Suppl 1):19-28.

53. HP, Maier W, van Nederveen FH, Suárez C, et al. Genetics of hereditary head and neck paragangliomas. Head Neck. 2014;36:907-16.

54. Burnichon N, Brière JJ, Libé R, Vescovo L, Rivière J, Tissier F, et al. SDHA is a tumor suppressor gene causing paraganglioma. Hum Mol Genet. 2010;19:3011-20. 